\title{
Isolated ocular flutter
}

向

Supplemental data at www.neurology.org
A previously healthy 30-year-old man presented with gradually worsening oscillopsia 2 weeks after an unusual headache; there was ocular flutter on examination (video on the Neurology ${ }^{\circledR}$ Web site at www.neurology.org) without other findings. Brain MRI was unremarkable. CSF showed mild pleocytosis $\left(11 \mathrm{cells} / \mathrm{mm}^{3}\right)$, but no evidence of active viral infections (herpes simplex virus, cytomegalovirus, varicella-zoster virus, Epstein-Barr virus, human herpesvirus 6, and measles). Serum antiganglioside antibodies (including anti-GQ1b antibody) were negative. The symptom resolved without treatment within 4 weeks. Ocular flutter is rare and may be isolated, although it is usually accompanied by generalized myoclonus or truncal ataxia. ${ }^{1,2}$ Brainstem (omnipause neurons in the paramedian pontine reticular formation ${ }^{3}$ ) or cerebellar dysfunction may contribute, as may abnormal pause cell control over saccadic burst neurons.

Saiko Nasu, MD, Akiyuki Uzawa, MD, PhD, Masahiro Mori, MD, PhD, Satoshi Kuwabara, MD, PhD

From the Department of Neurology, Graduate School of Medicine, Chiba University, Japan.

Study funding: No targeted funding reported.

Disclosure: The authors report no disclosures relevant to the manuscript. Go to Neurology.org for full disclosures.

Correspondence to Dr. Uzawa: auzawa@chiba-u.jp

1. Zaro-Weber O, Galldiks N, Dohmen C, et al. Ocular flutter, generalized myoclonus, and trunk ataxia associated with antiGQ1b antibodies. Arch Neurol 2008;65:659-661.

2. Wiest G, Safoschnik G, Schnaberth G, Mueller C. Ocular flutter and truncal ataxia may be associated with enterovirus infection. J Neurol 1997;244:288-292.

3. Schon F, Hodgson TL, Mort D, Kennard C. Ocular flutter associated with a localized lesion in the paramedian pontine reticular formation. Ann Neurol 2001;50:413-416.

\section{NeuroImages Are Free at www.neurology.org!}

All Neurology ${ }^{\circledR}$ NeuroImages can now be freely accessed on the Neurology Web site. See them at www.neurology.org, where you can also sign up for journal email alerts and check out other online features, including the Resident \& Fellow section, Neurology: Clinical Practice, and the weekly Neurology Podcasts. 


\title{
Neurology
}

\author{
Isolated ocular flutter \\ Saiko Nasu, Akiyuki Uzawa, Masahiro Mori, et al. \\ Neurology 2013;80;867 \\ DOI 10.1212/WNL.0b013e31828407a8
}

This information is current as of February 25, 2013

Updated Information \&
Services
Supplementary Material
References
Subspecialty Collections

Subspecialty Collections

Permissions \& Licensing

Reprints including high resolution figures, can be found at: http://n.neurology.org/content/80/9/867.full

Supplementary material can be found at: http://n.neurology.org/content/suppl/2013/02/23/80.9.867.DC1

This article cites 3 articles, 0 of which you can access for free at: http://n.neurology.org/content/80/9/867.full\#ref-list-1

This article, along with others on similar topics, appears in the following collection(s):

All Clinical Neurology

http://n.neurology.org/cgi/collection/all_clinical_neurology

All Movement Disorders

http://n.neurology.org/cgi/collection/all_movement_disorders

Oscillopsia

http://n.neurology.org/cgi/collection/oscillopsia

Information about reproducing this article in parts (figures,tables) or in its entirety can be found online at:

http://www.neurology.org/about/about_the_journal\#permissions

Information about ordering reprints can be found online:

http://n.neurology.org/subscribers/advertise

Neurology ${ }^{\circledR}$ is the official journal of the American Academy of Neurology. Published continuously since 1951, it is now a weekly with 48 issues per year. Copyright (C 2013 American Academy of Neurology. All rights reserved. Print ISSN: 0028-3878. Online ISSN: 1526-632X.

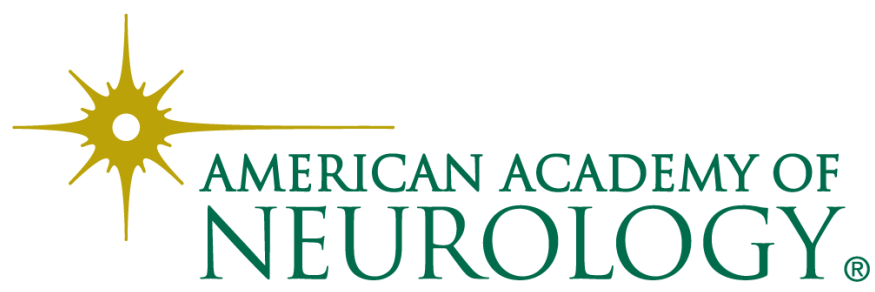

